Columbia Law School

Scholarship Archive

2006

\title{
'Une Chose Publique'? The Author's Domain and the Public Domain in Early British, French and US Copyright Law
}

Jane C. Ginsburg

Columbia Law School, jane.ginsburg@law.columbia.edu

Follow this and additional works at: https://scholarship.law.columbia.edu/faculty_scholarship

Part of the Comparative and Foreign Law Commons, and the Intellectual Property Law Commons

\section{Recommended Citation}

Jane C. Ginsburg, 'Une Chose Publique'? The Author's Domain and the Public Domain in Early British,

French and US Copyright Law, CAMBRidge LaW ReVIEW, Vol. 65, P. 636, 2006; Columbia Public LaW Research PAPER No. 06-120 (2006).

Available at: https://scholarship.law.columbia.edu/faculty_scholarship/1423

This Working Paper is brought to you for free and open access by the Faculty Publications at Scholarship Archive. It has been accepted for inclusion in Faculty Scholarship by an authorized administrator of Scholarship Archive. For more information, please contact scholarshiparchive@law.columbia.edu. 


\section{Columbia Law School}

Public Law \& Legal Theory Working Paper Group

Paper Number 06-120

'UNE CHOSE PUBLIQUE'? THE AUTHOR'S DOMAIN AND THE PUBLIC DOMAIN IN EARLY BRITISH, FRENCH AND US COPYRIGHT LAW

(version of 08/01/2006)

BY:

PROFESSOR JANE GINSBURG

COLUMBIA LAW SCHOOL

This paper can be downloaded without charge from the Social Science Research Network electronic library at:

$\underline{\text { http://ssrn.com/abstract }=928648}$ 
For Cambridge Law Journal, 1 August 2006

Inaugural Emmanuel College International Intellectual Property Lecture

Emmanuel College, Cambridge University, 11 May 2006

\section{'Une Chose Publique’? The Author's Domain and the Public Domain in Early British, French and US Copyright Law}

Jane C. Ginsburg*

Introduction

The public domain is all the rage. ${ }^{1}$ It is invoked to breach copyright's encroaching enclosure of what one might grandiloquently call the cultural commons of the mind. The heralds of our "remix culture"2 deploy the public domain to smash that icon of the entertainment-industrial complex, the Romantic Author. But even before the Author became Romantic, he still served as a shill for concentrated industry, then the printing-bookselling complex. ${ }^{3}$ Authors' moral claims of laborious entitlement merely masked the power grab of the printers. If we speak of a grab, we imply that copyright was seized from somewhere. So whence, in this account, was copyright wrested? From the public domain.

It is not my purpose here to take issue with the expanding normative role for the public domain. I do not for a moment dispute that the public domain is today and should remain copyright's constraining counterpart. In its composition, my idea of the public

\footnotetext{
* Morton L Janklow Professor of Literary and Artistic Property Law, Columbia University School of Law. Many thanks for research assistance to Matthew Batters, Columbia Law School class of 2006, without whom this project could not have been completed, and to Caleb Edwards, Columbia Law School class of 2008 and Christina Jodidio, University of Paris II class of 2007. Thanks also to Clarisa Long, Henry Monaghan, Thomas Nachbar, William R. Cornish, Lionel Bently, and especially Anne Barron.

1 The volume of academic writing on the public domain has vastly increased since the signal articles of David Lange, “Recognizing the Public Domain”, (1981) 44 Law \& Contemp. Probs. 147 and of Jessica Litman, “The Public Domain”, (1990) 39 Emory L.J. 965. See, e.g., Bernt Hugenholtz and Lucie Guibault, The Future of the Public Domain (forthcoming 2006) (collection of essays on the public domain from multiple contributors, including Pamela Samuelson and Julie Cohen); Tyler T. Ochoa, "Origins and Meanings of the Public Domain”, (2002) 28 U. Dayton L. Rev. 215; James Boyle, “The Second Enclosure Movement and the Construction of the Public Domain”, (2003) 66 Law \& Contemp. Probs. 33, 68; Mark Rose, "Nine-Tenths of the Law: The English Copyright Debates and the Rhetoric of the Public Domain", (2003) 66 Law \& Contemp. Probs. 75; Pamela Samuelson, "Mapping the Digital Public Domain: Threats and Opportunities”, (2003) 66 Law \& Contemp. Probs. 147 ; Yochai Benkler, "Free as the Air to Common Use: First Amendment Constraints on Enclosure of the Public Domain”, (1999) 74 N.Y.U L. Rev. 354, 361-62; Lawrence Lessig, The Future of Ideas: The Fate of the Commons in a Connected World (New York 2001). For a more skeptical view of “commons” discourse, see Anupam Chander and Madhavi Sunder, "The Romance of the Public Domain”, (2004) 92 California Law Review 1331..

2 See, e.g., Lawrence Lessig, Free Culture: How Big Media Uses Technology and the Law to Lock Down Culture and Control Creativity (New York 2004).

${ }^{3}$ See, e.g., Mark Rose, "The Author as Proprietor: Donaldson v Becket and the Genealogy of Modern Authorship”, in Brad Sherman and Alain Strowel (eds.), Of Authors and Origins: Essays on Copyright Law (New York 1994), 23, 30 ("it might be said that the London booksellers invented the modern author, constructing him as a weapon in their struggle with the booksellers of the provinces.”)
} 
domain may differ from some of yours', but we probably agree that there is and should be an ever-growing corpus of material over which no author or successor in title may exercise a private right. What provokes this lecture, by contrast, are what I perceive to be anachronistic assertions of the "immemorial" quality of today's aggressive concept of the public domain. ${ }^{4}$ Some of these arguments look to me like the Roche-Bobois "provincial" line of furniture: modern pieces with nicks and wormholes introduced to impart antique appeal. The normative claims for the public domain should persuade on their own, without the added patina of ancient precept. I therefore propose to examine what were the respective domains of author and public at copyright's inception, in $18^{\text {th }}-19^{\text {th }}$ century Britain, France and America. I acknowledge immediately that the search uncovers more ambiguity than certainty, more matters for further inquiry than tidy findings. I hope I will leave you with many questions, and that some of you will rise to the bait of seeking fuller answers.

We might start the inquiry into the respective domains of author and public with the observation that the term "public domain" did not exist in early copyright law. ${ }^{5}$ The phrase is a late arrival, entering English and American copyright discourse in the second half of the $19^{\text {th }}$ century, apparently borrowed from the French around the time of the drafting of the Berne Convention in the last quarter of the $19^{\text {th }}$ century. ${ }^{6}$ In France, the term had been employed by the mid $19^{\text {th }}$-century to mean expiration of copyright term. ${ }^{7}$ When imported into Britain and the US, the term was used in the same way. This does not mean that the broader concepts that the "public domain" today embraces did not exist in some form in the eighteenth century, but simply that no single locution conveniently and universally captured the concept of non property in works of authorship. $18^{\text {th }}$ century

\footnotetext{
${ }^{4}$ See, e.g., Ochoa, note 1 above, p. 222; Ronan Deazley, Re-Thinking Copyright (forthcoming 2006); L. Ray Patterson, "Free Speech, Copyright, and Fair Use”, (1987) 40 Vand. L. Rev. 1, 25 (the stationer's copyright "purported to preempt" the public domain while the Statute of Anne "created, or at least reestablished" the public domain); James Boyle, note 1 above, (2003) 66 Law \& Contemp. Prob. pp. 37-40 (arguing that a second enclosure movement is eating away at intellectual property that was previously in the public domain), Negativeland, "The Public Domain: Two Relationships to a Cultural Public Domain”, (2003) 66 Law \& Contemp. Probs. 239, 251 (the "ancient, universal view of art’s potential subject matter" encompassed everything, and has slowly been encroached by the development of capitalism); See also, Lawrence Lessig, "Dunwody Distinguished Lecture in Law: The Creative Commons" (2003) 55 Fla. L. Rev. 763, 764 (The public domain is a resource "that creators throughout history have drawn upon freely.").

${ }^{5}$ See, e.g., Mark Rose, note 1 above, p. 84 ("In the early period, [there was] no positive term in which to speak affirmatively about the public domain.”)

${ }^{6}$ Id., citing Jessica Litman, “The Public Domain”, (1990) 39 Emory L. J. 965, 975 n.60. The treatise Drone on Copyright (Boston 1879) appears to be one of the first American sources to use the term.

${ }^{7}$ See, e.g., Rapport fait au nom de la Commission rassemblée pour la rédaction d'un projet de loi sur la propriété d'arts, de sciences et des lettres, par le Comte de Ségur, Moniteur du 28 mars 1837, reprinted in 2 Fernand Worms, Etude sur la propriété littéraire, 37 (Paris 1878) (phrase « tomber dans le domaine public " used to mean expiration of copyright term). By contrast, ten years earlier, the legal encyclopedia, Recueil alphabétique de Questions de Droit by M. Merlin (4th ed 1828) devotes seven sections and 47 pages to « domaine public » but all concern public (and formerly royal) lands. See also, M. Merlin, Répertoire de Jurisprudence, 5th ed. (Paris 1826) pp. 259-327 (same).
} 
jurists employed terms like "publici juris,", or, in France, "propriété publique,", but they may not have meant it in the way some modern expositors use "public domain," to mean the non proprietary primordial soup from which we all sup, and freely digesting, bring forth further expression for the common delectation.

To ascertain the meaning of these terms at copyright's inception, we might essay a survey of the author's domain. If we know what rights the author enjoyed, and on what basis he enjoyed them, we might better grasp the realm that remains. I recognize that this approach might be charged with displacing the horse by the cart. But any order of precedence presents similar problems of barnyard organization, for I might equally well evoke the conundrum of the chicken and the egg. Did authors' rights spawn the public domain, or did copyright hatch from the common? So let's break out of this maddening circuit by asking a different question: In the beginning, in Britain, France and the US, was a published work a public thing?

I start with publication because the printing press gave rise to the conditions to which copyright and its predecessor privileges responded: the mass, and potentially uncontrolled, reproduction of copies of works, and the eventual rise of a population capable of reading them. Back in the days of the medieval scriptoria, copies were few and readers almost as scarce. Control over access to the physical copy limited the number of copies that could be made. ${ }^{10}$ And even then, some monasteries resorted to a kind of technological measure to prevent unauthorized access and copying: they chained the books to the walls. ${ }^{11}$

Almost as soon as there were printing presses there came printing privileges. ${ }^{12}$ Ruling authorities perceived two problems that privileges might resolve. Publishing would further the Renaissance revival of the classical authors as well as enhance the communication of contemporary Latin and vernacular literature and scholarship. But, along with making desirable works more available, uncontrolled publishing could also disseminate undesirable ideas. Second, uncontrolled publishing could discourage the financial undertaking required to print books: second-comers could undercut the profits of the first to invest in the labor and materials of printing. Limiting the number of printers would serve both the crown by controlling ideas, and the publisher by controlling competition. In some States separate authorities addressed censorship and competition. For example, in France, a royal minister supplied the required "approbation du roi," but the bookseller's guild, the "corporation des libraires," implemented the "privilège du

\footnotetext{
${ }^{8}$ See, .e.g, speech of Lord Camden in Donaldson v Beckett, 17 Parl. Hist. Eng. 953, pp. 997, 999 (1774).

${ }^{9}$ See, e.g., report of Le Chapelier, Archives parlementaires (Assemblée nationale) 13 january 1791 p. 210, discussed infra part III.

${ }^{10}$ As did the expense and labor-intensiveness of copying. See generally, Peter K. Yu, "Of Monks, Medieval Scribes and Middlemen”, 2006 Mich. St. L. Rev. 1, 7.

${ }^{11}$ The hooks and chains can still be seen at the monastery of Poblet in Spain.

${ }^{12}$ The first printing privileges were granted by the city-state of Venice in the second half of the fifteenth century. On the history of printing privileges see generally, Bruce Bugbee, The Genesis of American Patent and Copyright Law (Washington 1967) pp. 12-56; Frank Prager, “A History of Intellectual Property from 1545 to 1789”, (1944) 26 J Pat. Off. Soc. 711.
} 
roi.. ${ }^{13}$ In England, however, the Stationers Company ultimately covered both, ${ }^{14}$ an unsavory combination which has led some to discredit copyright by emphasizing its alleged origins in the suppression of sedition and heresy. ${ }^{15}$ (I say "alleged" because, for reasons which I hope will become apparent, copyright is not the alter ego of the printing privilege.)

With the printing privileges in place, a published work would not have been a "public thing," because the "public" was not free to copy the work. The literate public would have been free to read the works and to reap their ideas (or those ideas which passed political and ideological muster), but it is unlikely at the time that the new copying technology would have given rise to expectations of public entitlement to make and distribute copies. On the contrary, a 1677 King's Bench decision in a suit brought by the Stationers' Company, referring to an earlier House of Lords ruling, stated: "printing was a new invention, and therefore every man could not by the common law have the liberty of printing law books." ${ }^{16}$

But in England the printing privileges lapsed. The licensing act expired in 1695, and no statutory regime of exclusive rights replaced it until 1710's Statute of Anne. ${ }^{17}$ We might therefore consider whether this period fostered an expectation of non property (or of public entitlement) in published works which would have supplied the framework for interpreting the subsequent Statute of Anne. That is, should the Statute of Anne be seen as derogating from a prior public domain default, or does the statute fit within a proprietary landscape which persisted despite the expiration of the printing privileges?

Two factors make it unlikely that during this fifteen-year period a concept of the public domain as first principle, from which exclusive rights derogated, would have taken root and flowered. First, while the London booksellers who comprised the Stationers Company no longer enjoyed a royal monopoly, they still maintained a significant economic and technological advantage. They largely controlled the means of publishing, and they controlled their membership. ${ }^{18}$ So long as the guild could discipline its members into respecting each other's exclusivity, the conditions for propagating a public domain would not seem to have been in place.

Second, the lapsing of the Licensing Act terminated the vesting of exclusive rights in booksellers. But that did not necessarily mean that the concept of exclusive

\footnotetext{
${ }^{13}$ See generally Raymond Birn, "The Profits of Ideas: Privilèges en librairie in Eighteenth-Century France" (1970-71) 4 Eighteenth-Century Studies, 131.

${ }^{14}{ }^{14}$ See generally Cyprian Blagden, The Stationers' Company: A History 1403-1959 (London 1960).

${ }^{15}$ See, e.g., Pamela Samuelson, “The Copyright Grab”, (Jan. 1996) WIRED, p. 134.

${ }^{16}$ Company of Stationers v. Seymour 1677, 1 Mod 256. See also John Feather, Publishing, Piracy and Politics: An Historical Study of Copyright in Britain (1994) p. 46.

${ }^{17}$ An Act for the Encouragement of Learning by Vesting the Copies of Printed Books in the Authors or Purchasers of such Copies, 8 Anne c 19 (1710).

${ }^{18}$ For self-regulation within the printing and bookselling trades during the period between the licensing act and the Statute of Anne, see generally Isabella Alexander, "The Metaphysics of the Law": Drawing the Boundaries of Copyright Law 1710-1911 (thesis, Cambridge, 2005) para. [2.3]; Feather, see note 16 above, pp. 65-66; Blagden, see note 14 above, pp. 175-77.
} 
rights to copy and disseminate works of authorship died along with the printers' monopoly. Rather, another claimant to those rights appeared -- the author. As did a philosophical and legal theory to connect the author to the rights. One might query whether John Locke would have endorsed the extension of his labor theory of property to incorporeal property in the writings of authors. ${ }^{19} \mathrm{He}$ did, after all, urge the expiry of the Licensing Act, largely because he objected to the stationers' "Monopoly of all the Clasick Authers and scholers." ${ }^{20}$ However, he also supported a limited period (50-70 years) of post mortem exclusive rights. ${ }^{21}$ More importantly, in 1695 he collaborated on the text of a new licensing bill, which did not pass, but which would have vested both initial printing and reprinting rights in the author. Locke's draft, written in March 1695, appears to accept the premise of authorial proprietary rights: the text provides that the prohibition on printing was "to secure the Authors property in his copy." 22 This proposal is the precursor to the Statute of Anne, the first enactment to place the exclusive right initially in the hands of the authors rather than of printer-booksellers.

By the late seventeenth-century, authors' claims may, therefore, have been recognized as a matter of natural justice. But does natural justice translate into enforceable rights? Before authors were vested with statutory rights, could they advance a common law claim to exclusive rights in their works? Authors' common law claims could have occupied what might otherwise have been a legal vacuum (albeit not a de facto vacuum) when the Licensing Act lapsed. However, I have found no case preceding the Statute of Anne in which an author alleged a trespass of his property rights in a published, or unpublished, work. Stationers' Company practice recognized authorial rights in unpublished manuscripts, for the booksellers paid contemporary authors for the exclusive right to print their works. ${ }^{23}$ That right, nonetheless, might be said to stem from the author's control over the physical manuscript; the booksellers' practices do not necessarily evidence a common law property right in the author's disembodied words. ${ }^{24}$ That authors might enjoy enforceable incorporeal property rights in their works may well have been a new concept. ${ }^{25}$ The term "literary property" appears to have been coined

\footnotetext{
${ }^{19}$ See, e.g., Mark Rose, Authors and Owners: The Invention of Copyright (Cambridge 1993) p. 33

${ }^{20}$ John Locke, Memorandum (1694) against the renewal of the licensing act, reprinted in ES de Beer (ed) The Correspondence of John Locke (Oxford 1979), vol. 5, pp. 785-91. Self-interest may have played some role in Locke's objections: a bookseller's previously-grated printing privilege in Aesop's Fables blocked Locke's endeavor to publish his own edition. See Lewis Hyde, "Frames from the Framers: How America's Revolutionaries Imagined Intellectual Property”, (2005) Berkman Center for Internet \& Society, Research Paper No. 2005-08, 1, 11.

${ }^{21}$ Id.

${ }^{22}$ See Appendix to ES De Beer, note 20 above, p. 795. See generally, Laura Moscati, "Un "Memorandum" di John Locke tra Censorship et Copyright” (2003) LXXVI Rivista di storia del diritto italiano 69.

${ }^{23}$ See, e.g., Feather, note 16 above, p. 67.

${ }^{24}$ See, e.g., William Enfield, “Observations on Literary Property”, (1774) p. 30 reprinted in, The Literary Property Debate: Eight Tracts, 1774-1775 (London 1974) ( "The truth seems to be, that although the purchasing of a single copy may give the purchaser possession of the sentiments and expressions of a work, that is, of the composition itself, it doth not give him such absolute possession of it as to entitle him to ... the right of multiple copies")

${ }^{25}$ For the evolution of the concept of incorporeal property rights in works of authorship, see generally Brad Sherman and Lionel Bently, The Making of Modern Intellectual Property Law: The British Experience, 1760-1911, (Cambridge 1999) pp. 19-35. For the parallel, albeit later, evolution in France, see Laurent
} 
around 1707, when it was invoked in a petition from members of the Company to the House of Commons as part of the Stationers' ongoing attempt to restore the expired Licensing Act. ${ }^{26}$ In an earlier version of the Statute of Anne, from 1710, the preamble vaunts the rights of "Authors ... in whom ye undoubted Property of such Books and Writing as the product of their learning and labour remains . ..."27 If the concept of authorial property had not by 1710 received judicial imprimatur, the proposition that authors' intellectual labor justified a right perhaps cognizable at common law seems at least to have gained currency.

If authors' rights did not detract from a preexisting public domain, we might nonetheless posit that the Statute of Anne created both copyright proprement dit (that is exclusive rights arising out of the creations of authors rather than compensating or encouraging printers' investments) and the concomitant public domain. For if the statute delineated the author's domain (and, derivatively, the bookseller's, too), then everything the statute left out might be deemed publici juris. But that is taking a highly positivist view of the Statute of Anne. Whether or not literary property wasn't property before the statute, the effect of an interpretation that makes the statute the sole source of authors' rights is to create (or perpetuate) a vast zone of non property encircling the statute. Copyright becomes a little coral reef of private right jutting up from an ocean of public domain. In fact, the respective domains of author and public appear to have been much less clearly marked. Sticking with aquatic landscapes, we might say that the realm of copyright was a shoreline of uncertain contours. The Statute of Anne may have separated the waters from the lands, but it did not clearly tell us which was which.

I propose four ways to ascertain whether authors' rights were confined to the contours of the statute. Two address the existence of copyright, the others its scope. If the Statute of Anne furnished the sole basis for literary property, then the following propositions should be true:

1. Subject matter not included within the statute was not protected

2. Protection for covered subject matter depended on compliance with statutory formalities

3. Rights not included within the statute were not protected

4. The duration of rights was limited to the statutory term

As we will see, only the last of these ultimately proved to be correct, and it was hotly debated, even deplored, at the time by significant expositors of the common law. ${ }^{28}$ More importantly, resolution of the duration issue did not fully contain the author's domain.

Pfister, « La propriété littéraire est-elle une propriété? Controverses sur la nature du droit d'auteur au XIXe siècle », (July 2005) 205 RIDA 117

${ }^{26}$ See Feather, note 16 above, p. 56.

${ }^{27}$ Id.

${ }^{28}$ See infra at TAN xx. In the US, Donaldson was also criticized by the legal academy, see James Kent, Commentaries on American Law, (Boston 1826) part V, lecture XXXVI pp. 314-15. 
English judges continued both to grant extra-statutory protections, and to interpret hospitably claims that pushed the limits of statutory scope.

\section{Subject matter}

The Statute of Anne covered "any book," 29 a term the text did not define. A later enactment, the 1735 Hogarth's Act, ${ }^{30}$ provided for exclusive rights in prints and engravings. One might infer from the passage of a law specifically directed at certain works of art that "book" was limited to literary works, in book form, that is, in sheets printed and bound. Moreover, if the statute were creating new proprietary rights subtracted from the public domain, one might anticipate that the statutory grant would be narrowly construed. Most of the early cases did concern literary works in book form, but not all. Some of them addressed unpublished letters ${ }^{31}$ and manuscripts, ${ }^{32}$ an unpublished play, $^{33}$ published roadmaps ${ }^{34}$ and, finally, musical compositions, ${ }^{35}$ including music sold as single sheets. ${ }^{36}$ In the cases of maps and musical compositions, a generous reading of "book" could bring them within the statute, but the technique of statutory interpretation implied a property-friendly premise inconsistent with a view of copyright as derogating from a public domain default and therefore compelling narrow construction. Indeed, to fit musical compositions within "any book," Lord Mansfield in his 1777 decision in Bach $v$ Longman elevated the statute's preamble, which referred to "books and other writings," into operative language, ${ }^{37}$ though the actual provisions of the Act consistently specified only "books."

Similarly, beginning in 1741 with Alexander Pope's suit against Edmund Curl for unauthorized publication of letters written by Pope and sent to recipients from whom Curl apparently obtained them, ${ }^{38}$ the English courts routinely enjoined the unauthorized publication of letters and manuscripts. ${ }^{39}$ A manuscript might be considered a "book" (or an incipient one), and might also be assimilated to a chattel under its author's physical dominion. But letters were both less book-like, thus less clear candidates for statutory

\footnotetext{
${ }^{29} 8$ Anne c. 19 s 1.

${ }^{30}$ An Act for the Encouragement of the Arts of designing, engraving and etching historical and other Prints, by vesting the Properties thereof in the Inventors and Engravers, during the Time therein mentioned, 8 Geo.

II c.13 (1735).

${ }^{31}$ See, e.g., Pope v. Curl, [1741] 2 Atk. 342, 26 Eng. Rep. 608 .

${ }^{32}$ See, e.g., Duke of Queensberry v. Shebbeare, [1758] 2 Eden 329, 28 Eng. Rep. 924; Southey v. Sherwood, [1817] 2 Mer 435, 173 Eng. Rep. 1006.

${ }^{33}$ Macklin v. Richardson, [1770] Amb 694, 27 Eng. Rep. 451.

${ }^{34}$ Carnan v. Bowles, [1786] 2 Bro CC 80, 28 Eng. Rep. 45 and 1 Cox 283; 29 Eng. Rep. 1168, Cary v. Faden, [1799] 5 Ves 24, 31 Eng. Rep. 453, Cary v. Longman and Rees, [1801] 1 East 358, 102 Eng. Rep. 138.

${ }_{35}^{35}$ Bach v. Longman, [1777] 2 Cowp 263, 98 Eng. Rep. 1274.

${ }^{36}$ Clementi v. Golding, [1809] 2 Camp 25, 170 Eng. Rep. 1069; Clementi v. Goulding, [1809] 11 East 244, 103 Eng. Rep. 998.

${ }^{37} 2$ Cowp. at 624, 98 Eng. Rep. at 1274.

${ }^{38}$ Pope v. Curl, [1741] 2 Atk. 342, 26 Eng. Rep. 608.

${ }^{39}$ Id.; Duke of Queensberry v. Shebbeare, [1758] 2 Eden 329, 28 Eng. Rep. 924; Southey v. Sherwood, [1817] 2 Mer 435, 173 Eng. Rep. 1006; Perceval v. Phipps, [1813] 2 Ves \& Beam. 19, 24, 35 Eng. Rep. 225, 277; Thompson v. Stanhope, [1774] Ambler R. 737. 740, 27 Eng. Rep. 476, 477; Gee v. Pritchard and Anderson, [1818] 2 Swan 402, 36 Eng. Rep. 670, 679.
} 
coverage; and, having been sent to their intended recipients, had left the physical control of their authors. A traditional trespass claim thus would have been rather attenuated. But neither of these features gave Lord Harwicke difficulty. Since the defendant had assembled Pope's separate letters into a book, the statute's "book" condition was held to have been met. The chancellor followed this sleight of hand with another, by declaring that "any other learned work" was within the statute, including those their authors never intended to be published. He then established that a "learned work" need not aspire to pedagogy (or pedantry); informal letters on familiar subjects could do great service to mankind as well. He surmounted the chattel problem with similarly vaulting ease. Yes, the recipient had the "property of the paper," but the author's dispatch of the physical medium did not transfer the property in the words. The right of first publication thus was distinct from the ownership of the letter or the manuscript. Lord Hardwicke's distinction evidences the growing recognition that incorporeal subject matter can be the object of property. As Lionel Bently and Brad Sherman have demonstrated for British copyright, and Laurent Pfister for French copyright, this conceptualization did not come easily: $18^{\text {th }}$ century British copyright skeptics found the term "literary property" oxymoronic, deriding it as "property in nonsense." 40

\section{Formalities}

Was the first publication right a statutory property right or a common law property right? The Statute of Anne vested in authors the right of "printing" as well as "reprinting;" the former could have covered first publication. The overall focus of the statute, however, was directed towards the regulation of the printed, published copies -and the guild that purveyed them. Indeed, the printer/bookseller-centrism of the Statute of Anne has led many scholars to conclude that the figure of the author, having lent rhetorical flair to the preamble and moral appeal to the preceding lobbying, ${ }^{41}$ was nearly irrelevant to the actual regime the Statute established. ${ }^{42}$ Part of that regime included the conditioning of the statute's remedies on compliance with formalities. These requirements, notably registration of the work with the Stationers Company upon publication, were per se irrelevant to unpublished works. ${ }^{43}$ The role of formalities in a copyright system can tell us a lot about the premises underlying protection. If copyright is conditioned on compliance with formalities, then the right may be viewed in purely positivistic terms. No registration, no right, full stop. The policy underlying registration and similar notice-giving formalities is set out in the Statute of Anne:

whereas many persons may through ignorance offend against this Act, unless some provision be made whereby the property in every such book, as is intended by this act to be secured to the proprietor or proprietors thereof may be ascertained .... That nothing in this Act contained shall be construed to extend to

\footnotetext{
40 Sherman \& Bently, see note 25 above, p. 19 n.31, quoting An Enquiry Into the Nature and Origin of Literary Property, attributed to William Warburton (London, printed for Wiliam Flexney 1762).

${ }^{41}$ See, e.g., Mark Rose, note 19 above.

42 See, e.g.; Lyman Ray Patterson, Copyright in Historical Perspective (Nashville 1968) p. 147 (suggesting that giving the right to authors was merely a convenient means to attack the stationers' monopoly); Feather, see note 16 above, p. 51.

${ }^{43}$ See 8 Anne c 19 section 2. Moreover the term of protection ran from first publication, see section 1.
} 
subject any bookseller, printer or other person whatsoever, to the forfeitures or penalties therein mentioned ... unless the title to the copy of such book or books hereafter published, shall, before such publication, be entered in the Register Book of the Company of Stationers ... ${ }^{44}$

If the drafters of the statute feared that "persons [might] through ignorance offend against” the author's or proprietor's exclusive rights, that might imply that, absent registration of the work, the public was entitled to assume that the work was free to be printed or reprinted. In other words, the default position, away from which the author or proprietor must educate the public through proper registration, would be free appropriability. This in turn would suggest a skeptical and skimping view of the proprietary right.

The caselaw, however, indicates a different view. Non compliance with formalities seems not to have been raised as a defense when the claim concerned an unpublished work. Arguably, one who publishes an unpublished manuscript knows that he is invading the author's right. But, at least until Lord Hardwicke bifurcated the property rights in unpublished letters, ${ }^{45}$ it is not apparent that the recipient of a letter would have known that he was offending against the statute if he published the words the author had purposefully communicated to him. If unpublished letters were intended to be within the Statute of Anne, then the rationale for the formalities should have extended to them. If unpublished letters were not within the statute, then the author's claim must have lain in the common law of trespass, and the statute would not have supplanted that claim. In the latter event, the statute could not have defined the entire universe of enforceable literary property.

There is an additional explanation for the weakness of formality-based defenses, and consequently of the positivistic concept of copyright that formalities imply: even when it came to published works, the courts concluded that formalities conditioned only the special statutory remedies; common law remedies remained available when the author or proprietor had not registered the work with the Stationers Company. ${ }^{46}$ Thus, the statutory claim sat atop an established common law structure, enhancing, but not defining, the available relief. This observation, however, supports two conflicting

\footnotetext{
${ }^{44}$ Id. section 2.

${ }^{45}$ Pope v. Curl, [1741] 2 Atk. 342, 26 Eng. Rep. 608.

${ }^{46}$ See, e.g., Blackwell v. Harper, [1740] 2 Atk 93, 26 Eng. Rep. 458; Beckford v. Hood, [1798] 7 TR 620, 101 Eng. Rep. 1164.

Later interpretations of Hogarth's Act, however, required the engraver to have placed the date of first publication upon all distributed copies. See, Thompson $v$ Symonds, [1792] 5 Term. R. 41, 45, 101 Eng.Rep. 23, 26 (Lord Kenyon C.J. "The date is of importance, that the public may know the period of the monopoly."); Harrison v Hogg, [1827] 2 Ves. Jun. 323, 327, 30 Eng.Rep. 654, 656 (1794) (per R.P. Arden M.R.); Newton v Cowie, 4 Bing 234, 130 Eng.Rep. 759 (esp. per Best C.J. "It is impossible to suppose the legislative intended that the public should not have the protection afforded them by the first act against fraudulent continuance of the monopoly beyond the term prescribed by that act."). In Brooks $v$ Cock, [1835] 3 Ad. \& El. 138, 140-41, 111 Eng.Rep. 365, 366 Lord Denman CJ. rejected the analogy with Beckford v Hood, "It is the proprietor's own fault if he suffers a hardship. It is easy for him to comply with a regulation which is very simple and useful, and which makes the date part of the description of the plate to be protected".
} 
conclusions. The first conclusion would be that the courts' resort to common law remedies demonstrates that a common law right pre-existed the statute, and persisted concurrently. The second, competing, conclusion would be that when parliament creates a new right, it is assumed that remedies will be available to enforce it, whether or not the statute expressly includes remedies. ${ }^{47}$ Thus, any statutorily-created right can be enforced by common law remedies, in addition to whatever specific relief the statute sets out.

To determine whether a common law basis for proprietary rights ran concurrently with, or instead was subsumed within the statute, we turn to the third proposition, that the statute articulates the full and sole scope of the right.

\section{Scope of the right}

The Statute of Anne vested authors and proprietors with the rights to print, reprint and sell. In modern copyright parlance, these are the rights to reproduce and distribute the work. ${ }^{48}$ If these are the only legally cognizable rights, we would expect courts to reject any claims to protect a work against unauthorized public performance, or against unauthorized adaptation. Once again, the caselaw serves up an ambiguous response.

We will first consider the scope of the rights to print and reprint. Were these limited to dissemination of copies of the work in the same form and with the same contents as originally published, then partial copying or revision of the prior work would not have been held to infringe. The contrast of the Statute of Anne with Hogarth's Act could have supplied further textual support for crimping the concept of "printing and reprinting" in the Statute of Anne to integral copying. Hogarth's Act forbade reproducing the protected image "in the whole or in part, by varying, adding to, or diminishing from the main design." 49 It also targeted persons who "shall print, reprint or import for sale, ... any such prints, or any parts thereof." 50 The booksellers themselves seem to have appreciated the potential consequences of the absence from the Statute of Anne of "or any parts thereof" language. They petitioned parliament in 1735 for amendments extending the prohibition to unauthorized publication "in parcels at different times and in different publications," apparently in response to the growing practice of magazine serialization. This bill having failed, the booksellers petitioned two years later, also unsuccessfully, for a three-year embargo on unauthorized translations and abridgements. $^{51}$ The legislative record thus seems to favor narrow construction of the scope of the reproduction right in books.

The courts did, shortly following Hogarth's Act and the rejection of the booksellers' bills, devise a doctrine of "fair abridgement," permitting second-comers to update, correct, summarize, or partially copy copyrighted works. The basis of the fair

\footnotetext{
${ }^{47}$ See argument of counsel in Beckford v. Hood, 101 Eng. Rep. pp. 1165-66.

${ }^{48}$ See, e.g., 17 U.S.C. § 106(1)(3); Copyright, Designs and Patents Act, 1988 c. 48 § 16(a)(b) (Eng.).

${ }^{49} 8$ Geo. II c.13 (1735) section 1.

${ }^{50}$ Id.

${ }^{51}$ On the 1735 and 1737 bills, see generally, Ronan Deazley, On the Origin of the Right to Copy: Charting the Movement of Copyright Law in Eighteenth-Century Britain (1695-1775) (Oxford 1994) pp. 94-108.
} 
abridgement rule, however, seems to me more consistent with a labor-based property concept than with a narrow application of statutory text. In the 1740 decision in Gyles $v$ Wilcox, ${ }^{52}$ concerning the alleged copying of a law book, Lord Hardwicke considered whether "all abridgements" should "be brought within the meaning of this act of parliament.” Hardwick rejected a narrow interpretation of the statute, for reasons worth repeating here:

As to what has been said ... of the acts being a monopoly, and therefore ought to receive strict construction, I am quite of a different opinion, and that it ought to receive a liberal construction, for it is very far from being a monopoly, as it is intended to secure the property of books in the authors themselves, or the purchasers of the copy, as some recompence for their pains and labour in such works as may be of use to the learned world. ${ }^{53}$

Isabella Alexander has recently written eloquently regarding the public interest ("use to the learned world") aspects of Lord Hardwicke's reasoning in this decision, and of early British copyright in general. ${ }^{54}$ I propose to focus on the "recompense for [authorial] pains and labour." Lord Hardwicke stated that books that "are colourably shortened only" were "undoubtedly within the meaning of the act of parliament, and are a mere evasion of the statute." But a "fair abridgement" falls outside the act in that a "real and fair abridgement . . . may with great propriety be called a new book, because . . . the invention, learning, and judgment of the author is shewn in them." 55 In other words, because he has expended mental labor, a fair abridger is an author, too. The labor rationale that justifies the first author's property also confines it. The colorable shortener (or, to use Justice Story's later US characterization of the same lowlife figure, the facile user of the scissors ${ }^{56}$ ) is not an author because he has contributed nothing of his own to the prior work. In the case of a fair abridgement, by contrast, we encounter not an absence of property rights, but two contending property rights, both arising out of "invention, learning, and judgment."

The fair abridgement doctrine created a conceptual difficulty as challenging as the recognition of incorporeal property. If the fair abridger is an author, he cannot at the same time be an infringer. But if he cannot be an infringer, then, absent express statutory provision of an adaptation right, the statutory reproduction right will not reach unauthorized abridgements and revisions of works even when these may prejudice both the author's economic interest, by underselling the longer versions, and his moral interests by, as Lord Hardwicke recognized, "mistaking and curtailing the sense of an author."

52 [1740] 2 Atk 141, 26 Eng. Rep. 489.

532 Atk. at 143, 26 Eng. Rep. at 490.

${ }^{54}$ Alexander, see note 18 above, at para. [4.2].

${ }^{55} 2$ Atk. at 143, 26 Eng. Rep. at 490.

${ }^{56}$ See Folsom v. Marsh, 9 F. Cas. 342, 345 (C.C. D.Mass. 1841). On Folsom v. Marsh, see generally, R. Anthony Reese, "The Story of Folsom v Marsh: Distinguishing Between Infringing and Legitimate Uses", in Jane C. Ginsburg and Rochelle Cooper Dreyfuss (eds.), Intellectual Property Stories (New York 2005) p. 259.

572 Atk. p. 143, 26 Eng. Rep. p. 490. 
right, a reconceptualization achieved in the House of Lords' 1835 decision in d'Almaine $v$ Boosey. ${ }^{58}$ There is an understandable economic impetus behind the Lords' extension of the opera composer's copyright to encompass re-orchestrations of selections into dance tunes. By 1835, a significant middle class with the means to purchase and perform music at home had emerged, thus creating a market for derivative versions of musical works. (The same factors may have contributed to the 1809 King's Bench ruling in Clementi $v$ Goulding that a single sheet of music was a "book."59) But d'Almaine's rationale confronts head-on the conflicting claims of the second author -- and overcomes them by denigrating the quality of the adapter's authorship: "The original air requires the aid of genius for its construction, but a mere mechanic in music can make the adaptation or accompaniment." 60 If the second author is a genius-free mechanic, in other words, if he not really an author, then he can be an infringer. Anne Barron has pointed out that d'Almaine may be the first English judicial recognition of the Romantic Author. ${ }^{61}$ For our purposes, d'Almaine closes the circle the courts created in Gyles v Wilcox: articulating the scope of the author's rights not in terms of statutory text, but with reference to the nature of the second author's labor.

The other right we will explore is even more clearly extra-statutory. The Statute of Anne did not provide for public performance rights. This is understandable in light of its focus on the printing trade. But if a play were performed without authorization, what recourse would its author or proprietor (in this case, the theater manager) have? The few cases decided before parliament enacted a performance right in $1833^{62}$ are inconclusive. The earliest, Coleman $v$ Wathen, ${ }^{63}$ decided by the King's Bench in 1793, concerned an unauthorized performance of a play. The defendant had apparently memorized the plaintiff's work, An Agreeable Surprise, while it was being performed, and then to plaintiff's disagreeable surprise, performed it on a rival stage. The plaintiff cried "piracy!" and argued both that the performance should be considered a publication within the Statute of Anne, and that the author had rights independently of the Statute. The court dismissed the claim, stating that the performance was not a publication. The two succinct opinions do not address the claim of extra-statutory rights, but their silence may be interpreted as rejecting the second line of argument as well.

By contrast, in Morris v Harris (1814) ${ }^{64}$ and Morris $v$ Kelly $(1820),{ }^{65}$ injunctions issued against the unauthorized performance of published plays, but no reasoning is given as to the legal basis for the restraint. Finally, in Murray v Elliston, ${ }^{66}$ the King's Bench in 1822 addressed a claim arising out of an unauthorized performance of a tragedy

\footnotetext{
${ }^{58}$ [1835] 1 Y \& C Ex 288, 160 Eng. Rep. 117.

${ }^{59}$ Clementi v. Golding, [1809] 2 Camp 25, 170 Eng. Rep. 1069; Clementi v. Goulding, [1809] 11 East 244, 103 Eng. Rep. 998.

${ }^{60}$ [1835] 1 Y \& C Ex at 302, 160 Eng. Rep. p. 123.

${ }^{61}$ Anne Barron, “Copyright Law’s Musical Work”, (2006) 15 Social and Legal Studies, 101, 120-22.

${ }^{62}$ An Act to amend the Laws relating to Dramatic Literary Property, 3 Will. IV c.15 (1833).

${ }^{63}$ Coleman v. Wathen [1793] 5 TR 245, 101 Eng. Rep. 137.

${ }^{64}$ Unreported (Ch. 1814), cited in Richard Godson, Practical Treatise on the Law of Patents for Inventions and of Copyright (London 1823) 285.

${ }^{65}$ [1820] 1 Jac. \& W. 481, 37 Eng. Rep. 451.

${ }^{66}$ [1822] 5 B \& Ald 657, 106 Eng. Rep. 1331.
} 
published by Lord Byron. The defendant cited Donaldson $v$ Beckett ${ }^{67}$ (of which more momentarily) and Coleman $v$ Wathen ${ }^{68}$ to assert that no remedy could exist outside the statute, and the statute did not extend to performance rights. But the defendant then advanced an additional rationale for dismissing the action. Expounding on "the nature of copyright,” defendant's counsel urged:

The injury then which an author sustains by the violation of his copyright is this; that a stranger, without permission, disposes of the use and possession of this, his book, and thereby receives the profits to which he, the author, is justly entitled. If then the book be not in all reasonable strictness such as may be called the author's own book, as if it be a bona fide abridgement, Gyles $v$ Wilcox shews that the author has no remedy. Now, in the present case, a theatrical exhibition falls within the principle above laid down. Persons go thither, not to read the work, or to hear it read, but to see the combined effect of poetry, scenery, and acting. Now of these three things, two are not produced by the author of the work, and the combined effect is just as much a new production, and even more so than the printed abridgement of a work. ${ }^{69}$

The court's laconic (or laconically reported) dismissal of the action offers a clue to which of the two arguments the judges may have found most persuasive: "an action cannot be maintained . . . for publicly acting and representing the said tragedy, abridged in the manner aforesaid ..."70 I suggest we have here not an absence of statutory rights, but an excess of conflicting common law claims.

\section{Duration}

We turn now to the last of our four propositions, addressing the duration of copyright. Here, the statute definitively trumped any pre-existing or concurrent common law rights. I do not propose to re-tell the oft-told tale of Donaldson v Beckett, ${ }^{71}$ nor to enter the fray of sorting out which judge voted which way on the five propositions put to them: ${ }^{72}$ whether copyright existed at common law before publication; whether it existed at common law after publication; whether the Statute of Anne took away the common law right; whether the common law right was perpetual; whether the Statute of Anne took away the perpetual right. ${ }^{73}$ We do - more or less -- know the bottom line: whether or not common law copyright was perpetual and persisted past publication, the Statute of Anne

${ }^{67}$ [1774] 2 Bro PC 129, 4 Burr. 2408; 1 Eng. Rep. 837

68 [1793] Coleman v. Wathen, 5 TR 245, 101 Eng. Rep. 137.

${ }^{69} 5$ B \& Ald at 660, 106 Eng. Rep. at 1332.

${ }^{70} 5$ B \& Ald at 661, 106 Eng. Rep. at 1332 (emphasis supplied).

${ }^{71}$ For prior re-tellings, see, e.g., Deazley, note 51 above, pp. 191-210; Mark Rose, “Author as Proprietor” note 3 above; Feather, note 16 above pp. 89-95; Howard B. Abrams, "The Historic Foundation of American Copyright Law: Exploding the Myth of Common Law Copyright”, (1983) 29 Wayne L. Rev. 1119; Augustine Birrell, Seven Lectures on the Law and History of Copyright in Books (London 1899) pp. 99-138.

${ }^{72}$ See, e.g., Abrams, note 71 above; Deazley, note 51 above.

${ }^{73} 4$ Burr. at 2408, 98 Eng. Rep. At 357-58, 2 Bro. at 144-45, 1 Eng. Rep. pp. 846-47, 17 Parl. Hist. Eng. pp. $970-71$. 
limited the copyright term, at least for published works, to the 14 years provided by the statute, with an additional 14 years if the author were still living at the expiration of the first term. Because the peers did not address the five questions put to the judges, and most of them gave no reasons at all for their votes, ${ }^{74}$ we do not know which if any of the following propositions Donaldson $v$ Beckett stands for: that there was no common law copyright; that any common law copyright expired upon publication; that the Statute of Anne preempted common law copyright entirely; that the Statute of Anne preempted common law copyright to the extent it overlapped with statutory copyright, but left untouched those areas not specifically addressed by the statute. ${ }^{75}$

The controversy over common law copyright that culminated in Donaldson is also known as the "battle of the booksellers,"76 but some of its most heated rhetoric concerned authors. These included the lofty pronouncements of Lord Mansfield and Blackstone, ${ }^{77}$ as well as interested parties' broadsheets, extolling authors' labor-based claims to literary property. ${ }^{78}$ The other side tended to emphasize the public interest in the spread of ideas ${ }^{79}$ (though literary propertarians never asserted a copyright claim to ideas as such). ${ }^{80}$ Lord Camden's speech in Donaldson, if carefully excerpted, would take pride of place on anyone's Top Ten list of public domain advocacy. For example:

\footnotetext{
${ }^{74}$ See 17 Parl. Hist. Eng. p. 1003 (recording the names of those peers for the resulting 32-11 vote).

${ }^{75}$ See Mark Rose, “Author as Proprietor” note 3 above, p. 45 ("The Lords' decision did not touch the basic contention that the author had a property in the product of his labour.")

${ }^{76}$ See Birrell, note 71 above, p. 99.

${ }^{77}$ See, "Speeches or Arguments of the Judges of the Court of King's Bench" (1771) p. 94 (Lord Mansfield's opinion in Millar v. Taylor, pronouncing what is "just" for authors) reprinted in The Literary Property Debate: Seven Tracts, 1747-1773 (New York 1974); Sir David Rae, Lord Eskgrove, "Information For Mess. John Hinton, and Attorney; Against Mess. Alexander Donaldson, and Others” (1773) p. 44 reprinted in The Literary Property Debate: Six Tracts: 1764-1774, (New York 1975) (citing book 2, chapter 26, § 8 of Blackstone’s Commentaries).

${ }^{78}$ Francis Hargrove, "An Argument in Defence of Literary Property" (1774) p. 21; "Information for John MacKenzie of Delvine, Writer to the Signet, and Others, Trustees Appointed by Mrs. Anne Smith, Widow of Mr. Thomas Ruddiman, Late Keeper of the Advocates Library, Pursuers, Against John Robertson, Printer in Edinburgh, Defender” (1771) pp. 10-1 reprinted in The Literary Property Debate: Seven Tracts, 1747-1773; James Ralph, "The Case of the Authors by Profession or Trade, Stated With Regard To Booksellers, the Stage, and the Public" (1758) p. 2 reprinted in Freedom of the Press and the Literary Property Debate: Six Tracts, 1755-1770 (New York 1974); William Enfield, LL.D., "Observations on Literary Property” (1774) pp. 19-20 reprinted in The Literary Property Debate: Eight Tracts, 1774-1775 (New York 1974).

${ }^{79}$ J. MacLaurin, "Considerations on the Nature and Origin of Literary Property” (1767) p. 34 reprinted in Freedom of the Press and the Literary Property Debate: Six Tracts, 1755-1770 ("The perpetuating the Monopoly of Books, must inevitably enhance their Prices beyond all Bounds, the infallible Consequence of which is to retard, and indeed stop altogether the Progress of Learning."); "A Memorial for the Booksellers of Edinburgh and Glasgow, Relating to the Process Against Them by some of the London Booksellers; which Depended Before the Court of Session, and is now under Appeal” (1747) p. 12 reprinted in The Literary Property Debate: Seven Tracts, 1747-1773; Thomas Hayter, "An Essay on the Liberty of the Press, Chiefly as it Respects Personal Slander" (1755) pp. 38-9, reprinted in Freedom of the Press and the Literary Property Debate: Six Tracts, 1755-1770. See also "A Letter from a Gentleman in Edinburgh, to his Friend in London; Concerning Literary Property" (1769) p. 15 reprinted in Freedom of the Press and the Literary Property Debate: Six Tracts, 1755-1770 (charging that self-interest underlay Blackstone's espousal of the booksellers' position).

${ }^{80}$ Hargrove 36; "Information for John MacKenzie” p. 12; Rae, "Information For Mess. John Hinton" (1773) p. 17; William Enfield, “Observations on Literary Property” (1774) p. 30.
} 
If there be anything in the world common to all mankind, science and learning are in their nature publici juris, and they ought to be as free and general as air or water. They forget their Creator, as well as their fellow creatures, who wish to monopolize his noblest gifts and greatest benefits. Why did we enter into society at all, but to enlighten one another's minds, and improve our faculties, for the common welfare of the species? Those great men, those favoured mortals, those sublime spirits, who share that ray of divinity which we call genius, are intrusted by Providence with the delegated power of imparting to their fellow-creatures that instruction which heaven meant for universal benefit; they must not be niggards to the world, or hoard up for themselves the common stock. ${ }^{81}$

But read a little further, and we discover a less seductive vision. Lord Camden goes on to lament filthy lucre's defilement of the pristine calling of authorship:

Glory is the reward of science, and those who deserve it, scorn all meaner views: I speak not of the scribblers for bread, who teaze the press with their wretched productions; fourteen years is too long a privilege for their perishable trash. It was not for gain that Bacon, Newton, Milton, Locke, instructed and delighted the world; it would be unworthy of such men to traffic with a dirty bookseller for so much a sheet of letter press. ${ }^{82}$

Given the rise of the professional author in the $18^{\text {th }}$ century, this feature of Lord Camden's oration was retrograde even its day. ${ }^{83}$ As Catherine Macaulay then wryly observed, the need to pay the "sordid butchers and bakers . . . are evils which the sublime flights of poetic fancy do not always soar above." ${ }^{44}$ Camden's stance, and the outcome in the case, also evoked the ire of legal commentators of the time. Gilles Jacob's 1797 Law Dictionary attributes to Cambridge law don Edward Christian the confrontational assertion that because Donaldson "was contrary to the opinion of Lord Mansfield, of the learned Commentator [(Blackstone)], and of several other judges . . . every person may still be permitted to indulge his own opinion upon the propriety of it, without incurring the imputation of arrogance." 85 And such indulgences abounded. In his forthcoming

\footnotetext{
8117 Parl. Hist. Eng. p. 999.

${ }^{82}$ Id. p. 1000. Lord Camden's rhetoric evokes that of Boileau, almost a century earlier, deploring those who "disgusted with glory and famished for gain/indenture their muse to a bookseller/and convert a divine art into a mercenary trade.” See Boileau, chant IV Art poétique (1688-96):

Je sais qu'un noble esprit peut sans honte et sans crime

Tirer de son travail un tribut legitime

Mais je ne puis souffrir ces auteurs renommes

Qui, degoûtés de gloire et d’argent affamés,

Mettent leur Apollon au gages d'un libraire

En font d'un art divin un métier mercenaire.

${ }^{83}$ On "the development of authorship as a business" in the $18^{\text {th }}$ century, see, e.g., 1 Victor Bonham-Carter, Authors by Profession (London 1978) pp. 11-32; Brean S. Hammond, Professional Imaginative Writing in England, 1670-1740: “Hackney for Bread” (1997); A.S. Collins, Authorship in the Days of Johnson (1927).

${ }^{84}$ Catherine Macaulay, A Modest Plea for the Property of Copyright (Bath 1774) p. 15.

${ }^{85}$ Giles Jacob, The Law Dictionary (London 1797) “Literary Property,” $1^{\text {st }}$ page, col. 2 of entry
} 
book, Ronan Deazley conjures up a virtual conspiracy of early nineteenth-century commentators committed to undermining the public domain by diminishing Donaldson's impact. $^{86}$

III

Let us leave the cabal of British commentators and travel across the Channel to consider how the French envisioned the respective domains of author and public. French copyright today is generally considered, at least by "les anglo-saxons" -- by which the French curiously mean anglo-americans -- to be fundamentally authorial propertyoriented. ${ }^{87}$ Even the public domain, in the strict sense of copyright-expired works, is not absolutely property-free: authors' moral rights are perpetual, and can be invoked to protect the integrity of works whose authors have been dead well past the statutory postmortem period. ${ }^{88}$ The risk of rampaging moral rights-bearing remote heirs is not theoretical, as the publishers of a purported sequel to Les Misérables learned recently to their dismay. ${ }^{89}$

But it was not always thus. Of the three copyright systems here reviewed, France's was at first the closest to acknowledging a public domain default, emphasizing the public's property as the backdrop to private rights. Like England, France had a longstanding regime of printing privileges. These, however, ended not with the whimper of the lapsing of the Licensing Act, but with the bang of the night of August 4, 1789, and the general abolition of all privileges. ${ }^{90}$ Whatever the lingering de facto power of the corporation des libraries de Paris, de jure and politically the message was clear: henceforth, the press is free, not only of censorship, but also of proprietary claims.

The first French copyright enactment did not restore private rights in printed works; instead it created a dramatists' public performance right. This was not the principal motivation for the Law of January 13, 1791. Its reporter, Le Chapelier, was the moving spirit behind, and gave his name to, a later 1791 law dissolving guilds and corporations. So it should be no surprise that most of his report and the ensuing law aimed to repulse the pretensions of the Comédie française, whose members sought to retain their monopoly over the works of Corneille, Molière and Racine. Indeed, it appears from the report that the dramatists' first objective was to destroy the comédiens'

${ }^{86}$ Ronan Deazley, Re-Thinking Copyright (forthcoming 2006).

${ }^{87}$ By many French, too: a basic course in literary history and theory declares, "the French conception is personalist and favors the interest of the author over that of society, all the while permitting the free public circulation of ideas." -- Antoine Compagnon, Course " What is an Author » lesson 9, Intellectual Property, course given at the University of Paris IV-Sorbonne, division of French and comparative literature, www.fabula.org/compagnon/auteur9.php

${ }^{88}$ See Code de la propriété intellectuelle, art L-121-1, cl. 2.

${ }^{89}$ See Pierre Hugo v. Editions Plon, Paris Court of Appeals, decision of March 31, 2004, 202 RIDA (Oct. 2004) 292, note Pollaud-Dulian (Victor Hugo during his lifetime rejected all requests to create sequels to Les Misérables, the publisher who presents new novels as the continuation of Les Misérables therefore violates Hugo's perpetual moral rights; court awards damages to Hugo heir and to literary authors' society).

${ }^{90}$ Or more accurately, a couple of bangs, because, despite the abolition of privileges, the Paris Book Guild was not definitively suppressed until the decree of March 17, 1791, see Carla Hesse, Publishing and Cultural Politics in Revolutionary Paris 1789-1810 (Berkeley 1991) pp. 47-56 
exclusivity. The dramatists appear to have situated their second demand, for control over their works, within the rhetoric of the public domain. According to the report, the dramatists' petition

in seeking for the authors and their heirs or grantees the fullest property in their works during their life and five years following their death, recognizes and even invokes the rights of the public, and does not hesitate to admit that after the fiveyear period, the authors' works are a public property. ${ }^{91}$

Turning, after much execration of the Comédiens, to the dramatists' property right, Le Chapelier opened with a ringing affirmation of the principle of authorial property:

The most sacred, the most legitimate, the most indisputable, and if I may say so, the most personal of all properties is the work which is the fruit of a writer's thoughts.

This excerpt also makes the top ten list for selective quotation, however, because property-enthusiasts tend to leave Le Chapelier at this rhetorical high point, before he lets the other shoe drop. ${ }^{92}$ He continues:

But it is a property of a different kind from all the other properties. [Once the author has disclosed the work to the public] the writer has affiliated the public with his property, or rather has fully transmitted his property to the public. However, because it is extremely just that men who cultivate the domain of ideas be able to draw some fruits of their labors, it is necessary that, during their whole lives and some years after their deaths, no one may, without their consent, dispose of the product of their genius. But also, after the appointed period, the public's property begins, and everyone should be able to print and publish the works that have contributed to enlighten the human spirit. ${ }^{93}$

Article 2 of the proposed law declares that the works of authors who have been dead for five years "are a public property." "94 Thus there is no ambiguity about the end point of the author's domain. Moreover, Le Chapelier's concept of the public domain appears more extensive than expiration of term. The public's property interest is incipient as soon as the author discloses his work. Authors' labors justify their temporary property rights, but the public's more fundamental claims form an ever-present background.

\footnotetext{
${ }^{91}$ Archives Parlementaires, Assemblée nationale, 13 January 1791 p. 210.

92 See, e.g., Frédéric Rideau, La Formation du droit de la propriété littéraire en France et en Angleterre: Une convergence oubliée (Aix-en-Provence 2004) p. 263 and n. 751 (pointing out that quotations from Le Chapelier are «frequently truncated. »). For an attempt to trace the origins of the truncation, see Jane C. Ginsburg, “A Tale of Two Copyrights: Literary Property in Revolutionary France and America” in Brad Sherman and Alain Strowel (eds.), Of Authors and Origins: Essays on Copyright Law (Oxford 1994) pp. 131, 144 n.50

93 Archives parlementaires, see above, pp. 212-13.

${ }^{94}$ Id. p. 214.
} 
France did not enact a reproduction right until 2 years later, ${ }^{95}$ though laws were proposed in the interim, one of which strongly emphasized authors' proprietary rights, melding a variety of justifications, including France's debt to the writings of authors that shaped "the opinion that smashed all forms of despotism in France."96 This proposal included special statutory remedies more rugged than the Statute of Anne's damasking of infringing copies. An infringer would be exposed in the public square for three hours, chained to a placard labeled "thief infringer." -- An idea for record companies' pursuit of file sharers?

The 1793 Report of Lakanal accompanying the law installing a reproduction right begins defensively, deeming property in the "productions of genius" the "least contestable, the one whose increase cannot harm republican equality, nor offend liberty." The rhetoric then grows warmer, extolling "such a great revolution as ours" for making clear the simple justice of recognizing that property right. Lakanal later rebuts Le Chapelier's characterization of a published work as a "propriété publique": it makes no sense, he contends, for the author's right to disappear at the very moment at which he exercises it. Perhaps referring to Lord Camden's elevation of the author who writes only for glory, Lakanal contemptuously dismisses that notion, querying, "By what stroke of fate must it be that the man of genius, who devotes his waking hours to the instruction of his fellow citizens, might look forward only to a sterile glory, and might not claim the legitimate tribute of such noble work?"98

We can see that revolutionary rhetoric deliberately paired the author's domain with the advancement of revolutionary ideals. Authors deserve exclusive rights not only because they bring forth the products of "genius," but particularly because that genius bears a strongly republican stamp. But the concept of "propriété publique" was also a revolutionary rallying cry. It instituted what Professor Carla Hesse has called "a 'public domain' of democratic access to a common cultural inheritance."99 The concept lingers in the text of the laws, particularly regarding the role of formalities. The 1792 law amending the public performance right conditioned the vesting of the right on compliance with a notice-giving obligation. ${ }^{100}$ The 1793 law conferring reproduction rights imposed a requirement of deposit of copies with the national library. ${ }^{101}$ It is difficult to discern from the sparse caselaw addressing formalities whether French courts perceived them as conditions precedent to acquiring rights, or instead as means of perfecting pre-existing rights necessary to initiate an infringement action, ${ }^{102}$ or yet instead as a condition subsequent whose non fulfillment would divest the author of the copyright he initially

\footnotetext{
${ }^{95}$ Law of July 19-24, 1793.

${ }^{96}$ Report of François Hell, Archives parlementaires, 28 September 1791, p. 533, quoted in Rideau, see note 92 above, p. 261.

97 See Rideau p. 262, n 744.

${ }^{98}$ Archives parlementaires, 19 July 1793 p. 186.

99 Carla Hesse, “Enlightenment epistemology and the laws of authorship” (1990) 30 Representations 109, 129.

${ }^{100}$ Decree of 30 August, 1792, arts 4-6, Bulletin annoté des lois, décrets et ordonnances, 273 (1834).

${ }^{101}$ Law of 19-24 July, 1793, art. 6.

102 See Rideau, note 92 above p. 270.
} 
enjoyed. ${ }^{103}$ That the question was raised at all nonetheless indicates that the courts were uncertain of the boundary between the author's domain and the public's.

By contrast, two of our other tools for separating the author's domain from the public's -- subject matter and scope of rights - delineate a capacious authorial exclusivity, because the 1793 act grandly extended to "écrits en tout genre" (writings of all kinds); ${ }^{104}$ and the combination of the 1791 and 1793 acts covered the waterfront of rights, which may explain why France did not supplant these texts with a more fully developed code until 1957.

As for our fourth yard-stick, duration, we have seen that the term, while potentially much longer than the Statute of Anne's, was unambiguously terminal. The Statute of Anne provided for 14 years from publication, "and no longer" ${ }^{\text {"105 }}$ unless the author was still living at the end of that time, in which case another 14 years attached. ${ }^{106}$ But until Donaldson, it was vigorously argued that the cutoff applied only to the special statutory remedies, not to the existence of the property right itself. ${ }^{107}$ In France, because the positive law was clear, the advocates of perpetual copyright pressed their case before the legislature. The period from the decree of 1 Germinal year XIII (1804) creating exclusive rights in posthumously published works, to the law of 1866 setting the term of copyright at life +50 (where it largely remained until the EU Duration Directive of 1993 added another 20 years) saw increasingly acrimonious debates over the nature of copyright. ${ }^{108}$ Perpetualists argued that authors' rights were property, and property rights must, by their nature, endure forever. ${ }^{109}$ Their antagonists, whom I'll dub public domainists, emphasized that the rights contended-for were by their nature incorporeal and

${ }^{103}$ See Judgment of Oct. 23, 1806, Cass. crim., [1808] 2 Recueil Général des Lois et des Arrêts, [Dev. \& Car.] 1.299; Judgment of Nov. 26, 1828, Cour royale, Paris, [1828] 9 Dev. \& Car. 2.159. Both of these held that deposit of copies, rather than simply meeting a procedural requirement, gave rise to the copyright. In Judgment of Mar. 1, 1834, Cass. crim., 1834 Dev. \& Car. 1.65, the Cour de cassation states that the 1793 law "guarantees literary property, upon condition of deposit of two copies with the Bibliothèque nationale" and refers to the "loss of that property right through failure of deposit." Id. at 75. As a result of this decision, the question whether deposit under the 1793 law created, perfected, or merely served to prove, the copyright became moot: the court held that subsequent enactments (in 1810, 1814, and 1828) had substituted a different deposit requirement for that set forth in article 6 of the 1793 law. See also Judgment of Jan. 20, 1818, Cass. crim., 52 J. Pal. 5, considering compliance with formalities as giving rise to exclusive rights. The court states the plaintiffs "published the work in 1816 and fulfilled all the formalities prescribed for acquiring the exclusive right to sell." Id. pp. 12-13. Plaintiff's advocate made the same assumption when he contended that a French national first publishing abroad could nonetheless obtain copyright protection in France by completing the formalities to which the privilege is subject. Id. p. 8.

${ }^{104}$ Law of 19-24 July, 1793, art. 1.

1058 Anne c 19 section 1.

${ }^{106}$ Id secction 9.

${ }^{107}$ See, e.g., Millar v Taylor, [1769] 4 Burr 2303; 98 Eng. Rep. 201; Tonson v. Collins, [1761] 1 Black W 321; 96 Eng. Rep. 180.

${ }^{108}$ For a collection of the reports accompanying the various bills and rehearsing the arguments, see Fernand Worms, Etude de la propriété littéraire 2 vols. (Paris 1878).

${ }^{109}$ See, e.g, Edouard Laboulaye, La propriété littéraire au XVIIIème siècle (Paris 1859) pp. 18-9 (literary property is the same as other real property, and the author's right in it is a "droit perpétuel dans son principe »); J-B Jobard, Organon de la Propriété Intellectuelle (Paris 1851) pp. 54-55, 269. 
therefore incapable of ownership. ${ }^{110}$ A copyright thus could only be a contract between the author and society, in which the author received a limited term of exclusivity in recompense for his contributions to society. Joseph Prudhon, of notorious hostility to property in general, thundered against one of the draft perpetual copyright bills:

By enacting such a law, the legislature will have done far worse than paying the author an exorbitant price, it will have abandoned the principle of the chose publique, of the intellectual domain, and at great harm to the community. ... Let us not disinherit humanity of its domain . . . Intellectual property does not merely encroach on the public domain; it cheats the public of its share in the production of all ideas and all expressions. ${ }^{111}$

The Conseiller d'Etat Riché, reporting on the 1866 law, also emphasized the communal features of works of authorship, echoing Le Chapelier:

[Upon publication] the work is given over to the public; the author's property becomes a thing in common to all who encounter it ... It is no longer the property of its producer, this thing which grows and multiplies the further it goes from its producer. In the nature of things there is no literary property right in a work once it has been given over to the public. The nature of things has created the opposite of property, it has created a divestiture. ${ }^{112}$

As Professor Laurent Pfister has observed, a great deal of nineteenth-century French copyright (or anti copyright) rhetoric sounds a lot like today's cyber-libertarian “copyleft” avant la lettre. ${ }^{113}$ But Riché, while denigrating the concept of literary property nonetheless urged adoption of a law which, albeit not perpetual, installed one of the longest copyright terms in the world. This is one of the paradoxes of nineteenthcentury French copyright before the advent of moral rights: much of the rhetoric sought as a matter of principle to diminish the moral claims of author's rights by situating them in a broader landscape of the public interest. But in practice the positive law was considerably more protective than the UK's or the US.'

IV

\footnotetext{
${ }^{110}$ See, e.g., Augustin-Charles Renouard, Traité des droits des auteurs (Paris 1838) p. 203 (« Le droit au privilège est le prix du travail; c'est une rémunération dont la loi garantit la jouissance exclusive comme prix d'échange et dette de reconnaissance par lesquels la société paie l'utilité et le plaisir qu'elle retire de l’ouvrage. Il dérive de la qualité d'auteur. ») ; Edouard Calmels, De la Propriété et de la contrefaçon des œuvres de l'intelligence (Paris 1856) pp. 33-34; Paul Clément, Etude sur le droit des auteurs (Grenoble 1867) pp. $72-79$ (doctoral dissertation with extensive demonstration of how post-publication rights cannot fit usus, fructus, abusus characteristics of civil law property).

${ }^{111}$ Joseph Prudhon, « Les Majorats Littéraires : Examen d'un projet de loi ayant pur but de créer, au profit des auteurs, inventeurs et artistes, un monopole perpétuel » (1862), in Jan Baetens (ed.), Le Combat du droit d'auteur (Paris 2001) pp. 140,152-53.

${ }^{112}$ In Worms, see note 7 above, pp. 228, 244, 249.

${ }^{113}$ Laurent Pfister, "La propriété littéraire est-elle une propriété? Controverses sur la nature du droit d'auteur au XIXe siècle » (July 2005) 205 RIDA 117, 117-19.
} 
We come, at last, to the United States. In the first flush of freedom from England, the Continental Congress at Noah Webster's urging (not to say pestering), ${ }^{114}$ in turn urged the States to enact copyright laws to promote the production of instructive works of authorship. The pre-Constitutional copyright statutes revealed multiple motivations, mixing Statute of Annesque encouragements of learned men to write useful books with strong affirmations of authors' labor-based natural property rights. ${ }^{115}$ The Constitutional copyright clause also melds public domain and authorial property rationales. It empowers Congress "to promote the Progress of Science and Useful Arts by securing for limited Times to Authors and Inventors the exclusive Right to their respective Writings and discoveries." "116 The goal of the property right is to enhance public knowledge, but the rights - though limited in time -- are "secure[d]," not "granted," by Congress. As we shall see, the Supreme Court in 1834 declined to read "secured" to advert to a concurrent common law property right regime, and held instead that rights in published works were a purely statutory creation. ${ }^{117}$ But in 1787 , when the clause was drafted, selection of the term "secured" may have meant that the Framers understood copyright to have been a natural right pre-existing at common law. ${ }^{118}$ At least, Madison in Federalist 43 prompts that conclusion, for, in justifying the power granted to Congress to provide for copyright and patents, he asserts that "The copyright of authors has been solemnly adjudged, in Great Britain to be a right of common law."

If the starting point for federal copyright seemed to assume the author's preexisting property rights ${ }^{120}$, the first statutes, enacted in 1790 for maps, charts and books, ${ }^{121}$ and in 1802 for prints and engravings, ${ }^{122}$ prompt a different conclusion. The statutes were heavily inspired by (not to say largely plagiarized from) the Statute of Anne and Hogarth's Act. But the formalities imposed were more burdensome than their

\footnotetext{
${ }^{114}$ See Noah Webster, Origin of the Copy-Right Laws in the United States, in A Collection of Papers on Political, Literary and Moral Subjects (N.Y. 1843 \& B. Franklin ed. photo. reprint 1968).

115 The statutes are collected in Thorvald Solberg, (ed.), Copyright Enactments of the United States: 17831906 Copyright Office Bulletin No. 3, 2nd ed., rev., (Washington 1963) pp.1-21. See also, Francine Crawford, "Pre-Constitutional Copyright Statutes" (1975) 23 Bull. Copyr. Soc. 11. See particularly the statutes of Massachusetts and Connecticut . But see Alfed C. Yen, "Restoring the Natural Law: Copyright as Labor and Possession" (1990) 51 Ohio St. L. J. 517, 530-1 (early decisions indicate that courts perceived these statutes to express primarily economic motivations).

${ }^{116}$ U.S. Const., Art. I, § 8 cl. 8.

${ }^{117}$ Wheaton v. Peters, 33 US 591 (1834).

${ }^{118}$ For a review of various meanings to ascribe to "securing," see, e.g., Edward C. Walterscheid, "Inherent or Created Rights: Early Views on the Intellectual Property Clause" (1995)15 Hamline L. Rev. 81, 92-98 (inter alia, the Preamble to the US Constitution states that one of the purposes of the constitution is to "secure the blessings of liberty to ourselves and our posterity"; the Constitution didn't grant liberty - the war of Independence did that - but it was designed to protect and reinforce it). See also Edward C. Walterscheid, The Nature of the Intellectual Property Clause: A Study in Historical Perspective (Buffalo 2002) pp. 210-12.

${ }^{119}$ The Federalist Papers, No 43 (Madison) (Modern Library ed. 1937 at 279).

${ }^{120}$ But cf. Hyde, see note 20 above, pp. 18-27 (contending that the Framers conceived of copyright within the British land-ownership metaphors, but added a civic republican gloss which prompted them to think of intellectual (and of real) property as conferred for use for the public good).

1211790 Act, $\S \S 3$ and 4.

1221802 Act, $\S 1$.
} 
English counterparts. ${ }^{123}$ More importantly, where the English statutes and their early judicial interpretations confined formalities to specific statutory remedies, ${ }^{124}$ the US statutes conditioned the existence and enforceability of the right on compliance with the registration and deposit formalities. If there was any ambiguity regarding the availability of general common law remedies for violations of the 1790 Act in the absence of compliance with formalities, the 1802 Act, which added the notice formality and imposed it on 1790 Act works, left no doubt that the work would never attain federal protection if the formalities went unfulfilled. ${ }^{125}$ Formalities proved so essential to US copyright that one federal court, endeavoring in 1829 to determine whether a "daily price quote" could qualify for copyright, concluded that ephemera of this kind, whose utility and value vanish after a day, could not be copyrightable subject matter within the statute because they could not comply with formalities directing the proprietor to publish a record of the work's publication for four weeks in one or more newspapers, and to deposit the work within six months of publication. ${ }^{126}$

Apart from that decision, there appears to be no early caselaw addressing what subject matter came within the statutory categories of "any map, chart or book" or "prints and engravings.” But a review of early copyright registration records suggests that

\footnotetext{
${ }^{123}$ The 1790 Act required deposit of the work with the clerk of the federal district court upon publication of the work (§3), and deposit of 3 copies with the Secretary of State within 6 months of publication (§ 4). The 1802 act further required of a notice of copyright in at least one newspaper within one month of publication $(\S 1)$.

${ }^{124}$ See discussion above.

125 Justice Bushrod Washington so held in Ewer v. Coxe, 8 F. Cas. 917 (C.C.E.D. Pa. 1824). Accord, Nichols v Ruggles, 3 Day 145 (Ct. 1808). But see King v Force, 14 F. Cas. 521 (C.C.D. D.C. 1820) (suggesting the plaintiff could cure the omission of the date from his map by republishing the map with the date).

${ }^{126}$ Clayton v. Stone, 5 F. Cas. 999 (C.C. S.D.N.Y. 1829).

Republican fears of monopolies may have motivated the institution and judicial requirement of strict observance of statutory formalities. See, e.g., L. Ray Patterson and Craig Joyce, "Copyright in 1791: An Essay Concerning the Founders' View of the Copyright Power Granted to Congress in Article 1, Section 8 Clause 8 of the Constitution” (2003) 52 Emory L.J. 909, 941. On intellectual property and early American monopoly-phobia, see, e.g., Hyde, note 20 above pp. 13-29; Paul J. Heald and Suzanna Sherry, "Implied Limits on the Legislative Power: The Intellectual Property Clause as an Absolute Constraint on Congress" 2000 U. Ill. L. Rev. 1119, 1169; Yochai Benkler, "Constitutional Bounds of Database Protection: The Role of Judicial Review in the Creation and Definition of Private Rights in Information" (2000) 15 Berkley Tech. L. J. 535, 570 (the founders understood copyright as a monopoly to be "carefully circumscribed”). But see Tom Nachbar, "Constructing Copyright’s Mythology” (2002) 6 Green Bag 2d. 37, 45 (modern scholars' attribution of anti-monopoly animus to the framing of early US copyright laws is overstated); Edward C. Waltersheid, "To Promote the Progress of Science and Useful Arts: The Background and Origin of the Intellectual Property Clause of the United States Constitution” (1994) 2 J. Intell. Prop. L. 1, 55-6 (noting the few voices raised against giving Congress the power to grant monopolies, but concluding that "Just as in the Constitutional Convention itself, the issue of the limited monopolies authorized by the Intellectual Property Clause seems never to have been a point of contention in the state ratifying conventions. Although it was generally received with favor by those who thought about it, with Jefferson being the notable exception, the reality is that among the much more momentous issues addressed with respect to the new Constitution, very few actually gave much thought to it."); Paul M. Schwartz, William Michael Treanor, "Eldred and Lochner: Copyright Term Extension and Intellectual Property as Constitutional Property” (2003) 112 Yale L.J. 2331, 2364, 2384-5 (originalist arguments do not withstand careful examination, which reveals a spectrum of attitudes including support for monopolies among the Federalists and - in a limited manner - from the future Republicans).
} 
"book" was broadly understood to encompass dramatic and musical works. Thus, of 263 registrations made with the federal district court in Pennsylvania between 1790 and 1800, 2 were for plays, and 12 were for a variety of musical works, including a single song, and a collection of republican songs. During the same period in Massachusetts, of 198 registrations, two were for plays and 16 for musical works, of which 11 were hymnals. By contrast, in more worldly New York, with a total of 103 registrations, 5 of the registrations were for musical works, only one of them was a hymnal, the others were operas and dance music, along with 3 plays. ${ }^{127}$

With respect to rights protected, the general US approach was highly positivistic. Congress, not the courts, established and expanded the scope of copyright. Stowe $v$ Thomas $^{128}$ is a notable example. Harriet Beecher Stowe complained of the unauthorized translation of Uncle Tom's Cabin. But the statute then afforded rights only to print, publish and vend. The court characterized statutory copyright as a derogation from the public domain. It ruled that once Stowe's work was published it "bec[a]me as much public property as [the creations] of Homer or Cervantes.” Only those rights specified by the statute survived the dedication to the public that publication effected. According to the court, a translation might be a copy of Stowe's "thoughts or conceptions, but in no correct sense can it be called a copy of her book.",129

The legal positivism characterizing Stowe and similar decisions received fullest expression in Wheaton $v$ Peters, which is sometimes called the US counterpart to Donaldson, because the Supreme Court there rejected common law copyright. ${ }^{130}$ The dispute, however, concerned compliance with formalities, not expiration of the statutory term, (over which there seems to have been no dispute). ${ }^{131}$ The US high court's denial of common law rights was far clearer and more sweeping than the Peers'. Henry Wheaton had been the reporter of the decisions of the Supreme Court. Upon his retirement from that post, his successor Richard Peters not only published new volumes covering new decisions of the Court, but also reissued Wheaton's reports, without Wheaton's commentaries. Today, the decision is remembered principally for its holding, almost in passing in the last sentence of a lengthy majority opinion, that "the court are unanimously of the opinion that no reporter has or can have any copyright in the written opinions

\footnotetext{
${ }^{127}$ See Federal Copyright Records, 1790-1800 (James Gilreath, ed. 1987).

12823 F. Cas. 201 (C.C.E.D.Pa. 1853).

${ }^{129}$ Id p. 208.

${ }^{130}$ See, e.g., L. Ray Patterson and Craig Joyce, "Copyright in 1791: An Essay Concerning the Founders' View of the Copyright Power Granted to Congress in Article 1, Section 8 Clause 8 of the Constitution" (2003) 52 Emory L.J. 909, 928 n 45; Howard B. Abrams, see note 71 above, p. 1178.

${ }^{131}$ There seems not to have been much if any agitation in the US in favor of perpetual post publication copyright, perhaps because the US, in contrast to England, did not have a printer-booksellers' monopoly. See Tom Nachbar, "Constructing Copyright’s Mythology" (2002) 6 Green Bag 2d. 37, 45 (US publishers in fact were hostile to long copyright terms). Curtis' 1847 treatise on copyright, the first of its kind in the US, does not take issue with the limited duration of US copyright. On the contrary, he deems it desirable for both practical reasons (the dissipation of the right across successive generations of heirs), and policy considerations (quid pro quo). See George Ticknor Curtis, A Treatise on the Law of Copyright (Boston 1847) pp. 23-25.
} 
delivered by this court. . ."132 Most of the opinions and the arguments of counsel, however, addressed the legal foundation of authors' exclusive rights.

Wheaton's claim encountered the objection that he had no federal statutory rights because he had failed to comply with the multiple formalities imposed by the 1790 and 1802 statutes. Although insisting he had acquitted himself of those obligations, Wheaton also rejoined that if his statutory copyright claim failed, he nonetheless enjoyed enforceable common law rights. A 3-2 majority of the court followed Peters' argument that, whatever the state of affairs in England, in the US, copyright was purely statutory. The court determined that there was no federal common law, ${ }^{133}$ and, as to the States, before Independence, Pennsylvania, where Wheaton's reports had first been published and registered, had no common law of copyright in published works. As a result, copyright was a statutory creature from the start. The State copyright statutes of the preConstitutional period having been supplanted by the federal statute, it was solely to the 1790 and 1802 enactments that Wheaton must look for his post-publication rights. Congress having created the right, compliance with every jot and tittle of statutory formalities was essential to its vesting and enforceability.

Wheaton had tried to support his claim of common law rights by stressing that the Constitutional copyright clause and the 1790 Act "secured" the exclusive rights of authors, rather than "vesting" them, as had the Statute of Anne. The latter suggests a new grant, while the former evokes a confirmation of prior rights. If the constitution gave Congress the power to "secure" authors' rights, the argument went, that must imply that the rights pre-existed the constitution. Congress would be reinforcing, rather than creating exclusive rights in the writings of authors. Wheaton's counsel asserted: "Had the convention designed to take away, or to authorize congress to take away the common law property, they would have used the words vest, or grant; and would have carefully avoided the word secure."134

The majority made short work of this contention. It observed that the constitutional clause employs "securing" with respect to both the writings of authors and the discoveries of inventors. Yet it is clear that patents were not protected at common law. The word cannot, the majority insisted, at once mean pre-existing rights for copyright and newly created rights for patents. If the word is to have the same meaning for both, then it can only mean a new grant. ${ }^{135}$ The drafting history of the patent-

13233 US p. 668. For a general examination of Wheaton, see Craig Joyce, "The Story of Wheaton v. Peters: A Curious Chapter in the History of Judicature” in IP Stories, see note 56 above, p. 36.

13333 US p. 658.

1341834 US LEXIS 619 p. *** 73.

${ }^{135}$ Id p. 661.

The district court disposed of the "securing" argument in the following terms: "As I have mentioned the state statutes on this subject, I should notice an argument much pressed from the use in them of the word securing and not vesting the right. This is too slender a foundation to raise an acknowledged, pre-existing right upon. The same term is used in the act of congress of 1790, but was it an acknowledgement by congress that the United States, as such, had a common law which vested the right, and that they passed their law only to secure it?” Opinion of Judge Hopkinson, Appendix II to Wheaton v Peters, 1834 U.S. LEXIS 619, p. ***51. 
copyright clause, however, suggests that this reading was not in fact inevitable: the copyright and patent parts had originally been proposed separately and were merged into one clause, perhaps without full consideration of how the gerund would distribute across the now-combined indirect objects. ${ }^{136}$ But the Wheaton court's awareness or ignorance of this history does not matter. In 1834, any argument built on "securing" was doomed to fail, for reasons extraneous to competing conceptions of the author's and the public's domains.

The reasons go back to 1798, when the New York legislature granted Robert Livingston "the sole right and advantage of making and employing the steam boat" for a term of 20 years provided that Livingston within a year's time demonstrate that he had in fact built a steamboat. ${ }^{137}$ Livingston teamed up with Robert Fulton, but, unable to meet the deadline, they succeeded in obtaining successive extensions of the monopoly. In April 1808, they launched a 20-ton steamboat capable of going up river on the Hudson at the stately speed of four miles an hour. Whereupon the New York legislature granted them another five years' exclusivity, with the possibility of further grants to a total of 30 years. The New York courts routinely enforced these monopolies. ${ }^{138}$ Students of American constitutional law will recognize the facts underlying one of the Marshall court's signal federalism decisions, Gibbons v. Ogden, ${ }^{139}$ from 1824. The Supreme Court there held that New York's monopolies on steamboat ferry service on the Hudson conflicted with Congress' constitutional power to regulate interstate commerce. Gibbons $v$ Ogden thus is celebrated as one of the cornerstones of federal power; ${ }^{140}$ its relationship to intellectual property and its foreshadowing of Wheaton $v$ Peters, seems to have passed unobserved.

Counsel in Gibbons and in earlier New York cases involving the steamboat monopoly devoted much of their argument to New York's power to confer patents for inventions, a power asserted to be concurrent with the federal Congress' powers under the patent-copyright clause. In broad outline, the argument went as follows. The Constitution provides for Congress' power to "secure" the exclusive rights of authors and inventors. The term "securing" implies pre-existing rights. Copyright is such a right, as it has been recognized as a right at common law. Madison in Federalist 43 adverted to this

\footnotetext{
${ }^{136}$ See Bugbee, see note 12 above, p. 126 (Madison's record of the proposals before the Convention set out a list drawn up by Madison including the following: "To secure to literary authors their copyrights for a limited time" and "To encourage by premiums \& provisions, the advancement of useful knowledge and discoveries"; and a list by Charles Pinckney including "To grant patents for useful inventions" and "To secure to Authors exclusive rights, for a . . . certain time.”) For a detailed exploration of the drafting history of the patent-copyright clause, see Dotan Oliar, "The Immediate Origins of the Intellectual Property Clause" (2006)(on file with the author).

${ }^{137}$ The facts of the steamboat controversy are taken from Livingston v. van Ingen, 9 Johns 507 (NY Sup. 1812). See also IV Albert J. Beveridge, The Life of John Marshall (Boston 1919) pp. 397-460.

${ }^{138}$ See Livingston v. van Ingen, 9 Johns 507 (NY Sup. 1812); Livingston v. Ogden, 4 Johns. Ch. Rep. 48 (NY 1819). Livingston v. Tompkins, Id. 415 (NY 1820). Ogden v. Gibbons, Id. 150, 174 (NY 1819). North River Steam Boat Co. v. Hoffman, 5 Johns. Ch. Rep. 300 (NY 1821).

13922 U.S. 1 (1824).

${ }^{140}$ See e.g., IV Beveridge, above, p. 447 ("It is not immoderate to say that no other judicial pronouncement in history was . . . so interwoven with the economic and social evolution of a nation and a people, After almost a century, Marshall's Nationalist theory of commerce is more potent than ever ....)
} 
and further urged that inventions ought for the same labor-rewarding reasons also to come within Congress' power to regulate through a patent system. Thus, even though historically there was no common law patent, nonetheless the logic supporting common law copyright ought to apply to patents as well. In other words, there should be residual authority to recognize patents at common law. But, in the absence of federal common law, the relevant source of law will be the common law of the several States. Nothing in the constitutional clause suggests that the grant of authority to Congress was intended to displace the States' pre-existing rights. Therefore the States enjoy and retain the power to grant patent rights. ${ }^{141}$

The steamboat monopolists thus built from the foundation of "securing" an elaborate construct whose practical effect would have eviscerated federal power. New York's steamboat monopolies were creating precisely the kinds of barriers to interstate trade that had hobbled the new nation under the Articles of Confederation - and that had occasioned the adoption of the federal constitution in the first place. ${ }^{142}$ The monopolies conflicted with federal legislation governing navigation, a prerogative Congress enjoyed by virtue of its power to regulate commerce among the several States. Justice Marshall's opinion gives only the slightest hint of the roiling patent power controversy:

As this [analysis of the commerce power] decides the cause, it is unnecessary to enter in an examination of that part of the constitution which empowers Congress to promote the progress of science and the useful arts. ${ }^{143}$

The relevance of Gibbons $v$ Ogden to our exploration of the respective domains of author and public in early US copyright, I suggest, is to have taken "securing" out of contention as a basis for non statutory authors' rights pre-existing and concurrent with the federal statute. "Securing” had become a by-word for States' rights, for national subunits' exercise of an economic regulatory power which could undermine the larger nation state. If "securing" meant that the States not only previously had but concurrently enjoyed power to protect published works, the pairing of patent and copyright in the constitutional clause could mean that States also retained that power with respect to inventions. Whatever the deleterious effect on interstate commerce from State regulation of works of authorship, the impact stemming from competing state regulation of inventions was both apparent and unacceptable.

It is unlikely that Madison's reference in Federalist 43 to common law copyright was intended to encourage such a result. Indeed, Madison's remark in the same dispatch that the States "cannot separately make effectual provision" for the rights of authors and

\footnotetext{
${ }^{141}$ See, e.g., in Gibbons, 1824 LEXIS US pp. ***61-66; ***177-82 (petitioner); Livingston v. van Ingen, Emmet for Petitioners ("Congress have not power to confer a boon or reward. Its power is merely to secure a right for a limited time... . The state grants and creates an estate, and rewards the inventor. The patent merely secures the property to the inventor for a certain time. It proceeds as to authors, on the common law notion; as to inventors, on natural rights.")

${ }^{142}$ See, e.g., Federalist 22 (Hamilton) (defect of system under Articles of Confederation is absence of national power to regulate commerce, and consequent "interfering and unneighborly regulations of some States, contrary to the true spirit of the Union”).

14322 US p. 239.
} 
inventors ${ }^{144}$ suggests that he believed that only the federal entity could effectively ensure protection. ${ }^{145}$ This may not mean that he believed that the States should not be permitted to provide for authors and inventors, but it is doubtful that he anticipated that the States would compete with the federal government in making such provision. It is more probable that Madison's reference to authors' common law rights in Britain served the rhetorical purpose of equating authors' rights with the claims of natural justice. Whether or not Madison thought through the consequences of an enforceable common law right in the United States, in the absence of federal common law, implementing State common law rights in published works in the American system would have created an intractable federalism problem.

I do not wish to leave you with the impression that, after Wheaton, there was no common law copyright in the US, and that, accordingly, the author's domain was strictly limited to the narrow realm of the federal statutes. The public domain began with publication. An unpublished work, as a chattel, remained the object of common law rights, and this was still true until 1978. ${ }^{146}$ Over time, moreover, US courts elaborated a parallel universe of common law rights in works which, albeit technically "unpublished" because they had not been distributed in copies to the general public, had nonetheless encountered significant, indeed sometimes massive public exposure. ${ }^{147}$ Borrowing from old English decisions holding that a public performance was not a "publication,", 148 US courts created a common law right of public performance. ${ }^{149}$ Thus, notwithstanding Congress' addition, in 1856, of a public performance right to statutory copyright, ${ }^{150}$ a playwright could invoke common law rights to prevent a rival theater from producing his play so long as the original remained unpublished. And, because it was not a "publication," the public delivery of a lecture before enormous crowds would not forfeit the author's common law right to determine whether and when to distribute the work in copies thereafter. The rather strained notion of publication was motivated in large part by courts' awareness that, were the work to be deemed "published," and had the author not

\footnotetext{
${ }^{144}$ Federalist 43, above.

145 See also Madison, "Observations by JM [on the weaknesses of the Confederation]" ("Instances of inferior moment are the want of uniformity in the laws concerning naturalization and literary property"), quoted in Bruce Bugbee, The Genesis of American Patent and Copyright Law (Washington 1967) p. 125.

${ }^{146}$ The 1976 copyright act abolished the publication threshold for entitlement to federal copyright, which now "subsists" as of the creation and fixation of the work, see 17 USC § 102(a).

${ }^{147}$ See, e.g., Estate of Martin Luther King v. CBS, 194 F.3d 1211 (11 ${ }^{\text {th }}$ Cir. 1999) ("I Have a Dream" speech technically "unpublished" despite delivery before live audience of thousands, and television and radio broadcast to millions); see generally, William S. Strauss, Study No. 29 "Protection of Unpublished Works," in Studies on Copyright, Arthur Fisher Mem. Ed. 189 (1963).

${ }^{148}$ See Macklin v. Richardson, [1770] Amb 694, 27 Eng. Rep. 451; Coleman v. Walthen, [1793] 5 TR 245, 101 Eng. Rep. 137; Morris v Kelly, [1820] 1 Jac. \& W. 481, 37 Eng. Rep. 451.

${ }^{149}$ See, e.g., Boucicault v Fox, 3 F Cas. 977, 981 (C.C.S.D.N.Y. 1862)(equitable remedies available for unauthorized performance of unpublished play); Tompkins $v$ Halleck, 133 Mass. 32 (1882)(examining prior authorities and concluding that common law copyright subsists in unpublished play that has been publicly performed, and can be enforced both against unauthorized publication and unauthorized public performance).

${ }^{150}$ Act of August 18, 1856, 11 Stat. 138, c. 169.
} 
complied with all applicable federal statutory formalities, the work would go into the public domain, and all protection, state or federal, would be lost. ${ }^{151}$

Another area in which state common law and federal copyright diverged was the treatment of foreign authors. The first US copyright statute $\S 5$, emulating the Statute of Anne s 7, withheld protection from works of foreign authors first published abroad. Because this kind of provision remained in the US copyright law until 1891, English works were regularly pirated in the US. ${ }^{152}$ By contrast, unpublished works were protected at state common law, for reasons strongly evocative of natural rights, as an 1872 New York decision illustrates:

The right to literary property is as sacred as that to any other species of property. The courts of the State are open to an alien friend pursuing his property, and seeking to recover it from a wrong-doer, and there is nothing in any positive law, or in the policy of the government, which would close the door against the same alien friend seeking protection for the fruits of his mental labor, by restraining its publication against his wishes. The protection afforded by the common law to literary labor is very slight at best, but such as it is, it is accorded to alien friend and citizen alike, and both are regarded with equal favor. ${ }^{153}$

Thus, even in a system as positivist as US copyright, judges found occasion to recognize authors' extra-statutory rights, or, if you prefer, to compromise the public domain.

\section{$\underline{\text { Conclusion }}$}

It is so well established today that copyright cannot, and should not, last forever, ${ }^{154}$ that it may be difficult to understand the appeal of perpetual common law copyright in published works. But in both Britain and especially France, demands for

\footnotetext{
${ }^{151}$ See, e.g., Estate of Hemingway v Random House, 23 NY2d 341, 349 (1968) (“the courts are reluctant to find that an author has 'published' so as to lose his common-law copyright”).

Courts' efforts to avoid forfeitures may also explain the somewhat tortured US caselaw relating to sound recordings, see Study No 29, note 147 above, pp. 202-04. In this instance, two different forfeitures loom, first of the recorded musical composition, and second of the recorded performance. Under the 1909 Act regime, if sale of phonograms constituted "publication," and the recorded composition had not previously been published with notice or registered, then the sale of the recording would cast the composition into the public domain. With regard to the recorded performance, sound recordings were not included within federal copyright subject matter until 1972, Pub. L. No. 92-140, 85 Stat. 391 (1971), as amended by Pub. L. No. 93-573, 88 Stat. 1873 (1974) (federal protection for sound recordings fixed and published with notice on and after Feb. 15, 1972). As a result, were pre-1972 recordings deemed "published," they would have immediately gone into the public domain. Hence the judicial rulings that the sale and distribution of phonograms did not "publish" the performances, which, accordingly, remained subject to common law copyright. See Capitol Records v. Naxos of America, 4 N.Y.3d 540 (2005); Capitol Records v. Mercury Records Corp., 221 F.2d 657 (2d Cir. 1955)

${ }^{152}$ See generally Catherine Seville, Books, Buccaneers and the Black Flag in the Nineteenth Century (forthcoming 2006).

${ }^{153}$ Palmer v. De Witt, 47 NY 532, 539 (1872).

${ }^{154}$ But see UK CDPA 1988 c. 48 § 301 (potentially perpetual royalty right in JM Barrie’s "Peter Pan”), discussed in Catherine Seville, "Peter Pan’s Rights: “To Die Will be an Awfully Big Adventure” (2003) 51 J. Copyr. Soc. 1, 3-7.
} 
perpetual copyright persisted into the $19^{\text {th }}$ century. The expression "fall into the public domain" evokes the devastation of a fall from grace. Indeed, the $19^{\text {th }}$-century poet Alfred de Vigny amplified the sense of desolation: he evoked the expiration of copyright as "tomber dans le gouffre du domaine public" - to fall into the sink hole of the public domain. ${ }^{155}$

Gallic hyperbole notwithstanding, I think perpetuity was the punchline of a syllogism whose first proposition may have been the most important for authors' rights advocates: an author's intellectual labor gives rise to property rights; property rights are perpetual; therefore the author's right must be perpetual, too. To question the perpetuity of the right may be to unravel the syllogism, and undermine its premise. If copyright is not perpetual, then it cannot be property. If it is not property, then authors' efforts are denigrated; authors become uniquely disadvantaged among those who labor. ${ }^{156}$ This, to echo Lord Mansfield's celebrated litany in Millar v Taylor, is not "just." "157 Finally, there may be more than felt justice animating the calls for an endless author's domain; then as now, copyright advocates have had literary affinities, unfulfilled artistic yearnings reluctantly redirected toward juridical rather than creative endeavors. Blackstone himself was one of these closeted copyright lawyers. ${ }^{158}$ Yielding to his Arcadian urges, he penned the wistful "Lawyer's farewell to his muse," which, in conclusion, I shall unfairly (but mercifully) abridge:

\section{The Lawyer's Farewell to His Muse}

\section{Written in the Year 1744 by William Blackstone}

As, by some tyrant's stern command, A wretch forsakes his native land, In foreign climes condemn'd to roam An endless exile from his home;

So I, thus doom'd from thee to part, Gay queen of Fancy and of Art, Reluctant move, with doubtful mind, Oft stop, and often look behind.

\footnotetext{
155 Alfred de Vigny, «De mademoiselle Sédaine et de la propriété littéraire, Lettre à messieurs les Députés » (1841) reprinted in Jan Baetens, (ed.), Le Combat du droit d'auteur, Anthologie historique (Paris 2001) pp. 107, 112-13.

${ }^{156}$ Cf. E. Laboulaye, Etudes sur la propriété littéraire en France et en Angleterre (Paris 1858) p. xii (criticizing the 1793 French copyright law for making authors' rights "of all property rights the most humble and the least protected").

${ }^{157} 4$ Burr. pp. 2398-99; 98 Eng. Rep. pp. 252-53.

${ }^{158}$ Joseph Story also joins the coifed company of poètes manqués; in 1800, perhaps in youthful indiscretion (he was 21), he published an 83-page poem, "The Power of Solitude." His son seems to have deemed the effort worthy of obscurity, for he did not include it among Story's posthumously published miscellaneous papers, see William Wetmore Story (ed.), The Miscellaneous Writings of Joseph Story: Associate Justice of the Supreme Court of the United States and Dane Professor of Law at Harvard University (Boston 1852).
} 
Me wrangling courts, and Stubborn Law, To smoak, and crowds, and cities draw; There selfish Faction rules the day, And Pride and Av'rice throng the Way:

Adieu, celestial Nymph, adieu:

Shakespear no more thy sylvan son, Nor all the art of Addison, Pope's heav'n-strung lyre, nor Waller's ease, Nor Milton's mighty self must please:

Instead of these, a formal band

In furs and coifs around me stand;

With sounds uncouth and accents dry That grate the soul of harmony, Each pedant sage unlocks his store Of mystic, dark, discordant lore; And points with tott'ring hand the ways That lead me to the thorny maze. There, in a winding, close retreat, Is Justice doom'd to fix her seat, There, fenc'd by bulwarks of the Law, She keeps the wond'ring world in awe,

Then welcome business, welcome strife, Welcome the cares, the thorns of life, The visage wan, the pore-blind sight, The toil by day, the lamp at night, The tedious forms, the solemn prate, The pert dispute, the dull debate, The drowsy bench, the babling Hall, For thee, fair Justice, welcome all! 